\title{
INTERACTIVE E-BOOK FOR PHYSICS LEARNING: ANALYSIS OF STUDENTS' CHARACTERS AND CONCEPTUAL UNDERSTANDING
}

\author{
Anisa Nur Septikasari ${ }^{1}$, Maison $^{2 *}$, Nazarudin $^{3}$ \\ 1,2,3 Department of Scince Education, Postgraduate Program, Universitas Jambi, Indonesia \\ *Corresponding author: maison@unja.ac.id
}

\begin{tabular}{|c|c|}
\hline \multirow{2}{*}{$\begin{array}{l}\text { Article Info } \\
\text { Article historv: }\end{array}$} & ABSTRACT \\
\hline & The national education curriculum is concerned with character \\
\hline $\begin{array}{l}\text { Received: December 06, } \\
2020\end{array}$ & $\begin{array}{l}\text { building. The development of media with character needs to be } \\
\text { done to strengthen character and to help students understand the } \\
\text { momentum and impulses concept. This study aims to (1) develop }\end{array}$ \\
\hline Accepted: February 26, 2020 & an interactive e-book and (2) describe the character and \\
\hline Published: March 13, 2021 & $\begin{array}{l}\text { understanding of students' concepts after using the e-book. The } \\
\text { development model used Lee \& Owens with the stages: analysis, }\end{array}$ \\
\hline Keywords: & $\begin{array}{l}\text { design, development and implementation, and evaluation. An } \\
\text { interactive e-book was prepared by combining character values in }\end{array}$ \\
\hline $\begin{array}{l}\text { Conceptual understanding } \\
\text { Interactive e-book } \\
\text { Students' characters }\end{array}$ & $\begin{array}{l}\text { the content, discussion sheets, and online evaluation. The e-book } \\
\text { product contains images, videos, text input functionality and can be } \\
\text { accessed via a smartphone. Students can study matter, momentum, } \\
\text { and impulses without the basis of space and time. The results of the } \\
\text { study state: (1) interactive e-books are feasible and easy to use by } \\
\text { students (2) e-books that provide character reinforcement and are } \\
\text { effective in increasing understanding of concepts in } 10 \% \text { low } \\
\text { categories to } 60 \% \text { high categories }\end{array}$ \\
\hline
\end{tabular}

\begin{tabular}{|c|c|}
\hline \multicolumn{2}{|c|}{$\begin{array}{l}\text { E-BOOK INTERAKTIF DALAM PEMBELAJARAN FISIKA: } \\
\text { ANALISIS KARAKTER DAN PEMAHAMAN KONSEP SISWA }\end{array}$} \\
\hline & ABSTRAK \\
\hline Kata Kunci: & Kurikulum pendidikan nasional berkaitan dengan pembentukan \\
\hline $\begin{array}{l}\text { Pemahaman Konsep } \\
\text { E-book interaktif } \\
\text { Karakter Siswa }\end{array}$ & $\begin{array}{l}\text { karakter. Pengembangan media bermuatan karakter perlu dilakukan } \\
\text { untuk penguatan karakter dan membantu siswa memahami konsep } \\
\text { momentum dan impuls. Penelitian ini bertujuan untuk (1) } \\
\text { menghasilkan e-book interaktif dan (2) mendeskripsikan karakter } \\
\text { dan pamahaman konsep siswa setelah menggunakan e-book. Model } \\
\text { pengembangan menggunakan Lee \& Owens dengan tahapan: } \\
\text { analysis, design, development and implementation, serta } \\
\text { evaluation. E-book interaktif disusun dengan memadukan nilai } \\
\text { karakter pada isi materi, lembar diskusi, dan evaluasi online. } \\
\text { Produk e-book berisi gambar, video, fasilitas input teks serta dapat } \\
\text { diakses melalui smartphone. Siswa dapat mempelajari materi } \\
\text { momentum dan impuls tanpa dibatasi ruang dan waktu. Hasil } \\
\text { penelitian menyatakan (1) e-book interaktif layak dan mudah } \\
\text { digunakan oleh siswa (2) e-book berpotensi memberi penguatan } \\
\text { karakter dan efektif meningkatkan pemahaman konsep siswa } \\
\text { dengan skor } 10 \% \text { berkategori rendah menjadi } 60 \% \text { berkategori } \\
\text { tinggi }\end{array}$ \\
\hline
\end{tabular}




\section{INTRODUCTION}

One of the digital innovations in learning resources is that printed teaching materials have begun to be developed into digital teaching materials, such as electronic books. Ebooks have greater flexibility and accessibility compared to printed books [1],[2]. The government through the Ministry of Education and Culture has made e-books in the form of electronic school books. However, these electronic school books do not have much character value and tend to be like printed books, without the necessary simulations and interactive media. E-books should be able to contain content that displays interactive simulations by combining text, images, audio, video, and animation so that learning becomes more interesting and fun [3].

The development of technology and information also has a negative impact on education, such as making it easier for students to access information outside the context of learning during learning, facilitating plagiarism while doing assignments, and making students less communicative because they focus on games or social media. According to Chusna, The use of gadgets, which is a technology product, can also affect the character development of students, for example, students become unable to communicate optimally with their surroundings [4].

To overcome this, efforts to strengthen character in students are needed. One of the government's efforts to strengthen student character is through the national education curriculum related to character. Embedding character in learning can be done by utilizing learning media [5]. The use of media in learning tends to be limited to facilities to make it easier for teachers to deliver subject matter [5]. Therefore, it is necessary to develop media such as e-books that can teach cognitive skills and character that are designed according to needs. Through character-based learning, such as being accustomed to being honest, disciplined and independent, curious and communicative in doing assignments, it is hoped that it can produce good character and affect activities outside the classroom. [6].

Based on the results of the analysis conducted at SMA N 3 Jambi city, it was found that physics learning uses a national curriculum related to character, but the use of media in learning is still not optimal. Students also think that Physics is a difficult subject and the concepts are interrelated, so that if you do not master one concept, it will be difficult to learn other concepts. This statement is in line with opinion [7][8]. Learning Physics contains facts, concepts, laws and theories to solve problems in everyday life [9][10]. One of the difficult physics topics to understand is the momentum and impulses. This difficulty can result in a lack of understanding of students' concepts and errors in understanding concepts. Students' errors in interpreting the theory or understanding of students' concepts that are not in accordance with the theory of experts are called misconceptions [11].

The results of previous research on understanding concepts in momentum and impulse inform that the average percentage of misconceptions on momentum and impulse in SMA Muhammadiyah and SMAN 1 Arjasa is 14\% with the low category [12]. Furthermore, the results of identification of 34 students by Anggarini found that there were 29 students who experienced misconceptions with the highest percentage of misconceptions $42.86 \%$ on the sub-topic of energy conservation, and momentum [13]. One of the appropriate learning models to reduce misconceptions is problem-based learning, this is in line with the research results of O. Akinoğlu and R. Ö. Tandoğan which stated that problem-based learning affects conceptual development and reduces student misconceptions [14]. Interactive media such as e-book has also proven effective in reducing students' misconceptions on the subject of dynamic electricity [15] and e-books are also effective in enhancing the learning experience of students [16]. In addition, other 
studies also show that students who use media in learning experience better conceptual improvements than students without media assistance [17]

Various techniques for measuring students' conceptual understanding and misconceptions have been widely used, one of which is a four-tiered diagnostic test [18][20]. When compared with previous studies that only used multiple choice questions [12] and three-tier test [13], The four tier format diagnostic test provides more detail in determining the criteria for understanding concepts and misconceptions. The four tier test can reveal answers, confidence in the answers, reasons, and the level of confidence of students regarding the reasons given [21]. Four-tier diagnostics can also show parts of the material that require deeper learning with different methods for students [18].

Based on these problems, this study focused on (1) developing interactive e-book and (2) describing students' character and conceptual understanding after using interactive e-book on momentum and impulse. In previous research [22]-[24] Regarding physics ebooks, most e-books can only be accessed via computer, do not contain characters, and do not reach to analyze students' understanding as a result of using e-books. The e-book developed in this research combined character values in the content, discussion sheets, and evaluation and can be run using a computer or smartphone. Through interactive e-book, students can learn impulses and momentum without being limited by space and time. The character content in this e-book was limited to honest, disciplined, independent, curious, and communicative characters. The e-book product also contains image, video and text input facilities and is operated using the Foxit PDF Reader.

\section{METHOD}

The development model used is Lee and Owens' model [25] with the following stages: 1) assessment and analysis, (2) design, (3) development and implementation, and (4) evaluation. The research procedure can be seen in Figure 1.

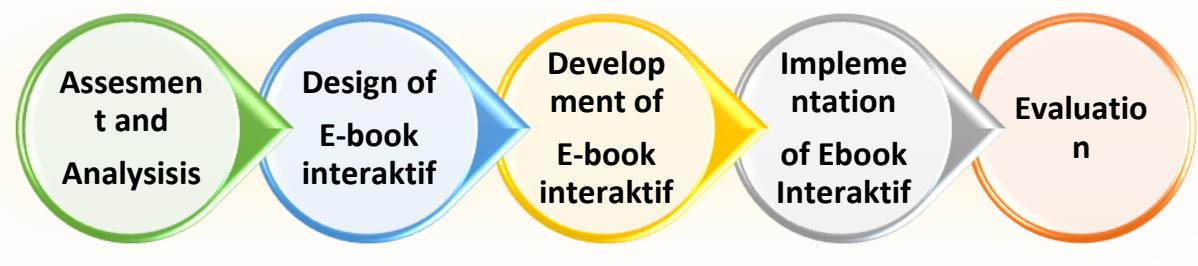

Figure 1. Development Procedure [25]

Respondents of this study were students of class XI MIA SMA Negeri 3 Jambi. The individual trial involved 3 students with various ability characteristics, namely high, medium, and low abilities. The small group trial involved 9 students with various ability characteristics. Diagnostic misconceptions involved 49 people. The diagnostic stage of misconceptions uses the One Group Pretest-Posttest Design [26] with comparing the results of test before and after using the e-book.

The instruments used in the study were (1) open questionnaire for expert validation, (2) interview guidelines for practitioner validation, (3) interview sheets and observation sheets for student responses, and (4) misconception diagnostic tests to determine the effectiveness of the e-book in improving student understanding. Open questionnaires are used to provide an opportunity to the respondents to express their opinions and analyzes [27], and interview guides can obtain more accurate data [28]. 
The instrument of expert validation, practitioner validation, and student responses used the content or concept validity test. The misconception instrument was made by adapting research that developed a four-tiered diagnostic test to identify misconceptions in momentum and impulse material. [29]. A four-tier diagnostic test instrument consisting of multiple-choice questions with four levels. The first level is multiple choice questions and answers, the second level is the level of confidence regarding the choice of answers, the third level is the reason for the answers given, and the fourth is the level of confidence of the reasons [21][30]. Table 1 is the category of misconceptions based on the percentage [31].

Table 1. Category Percentage Level of Misconception

\begin{tabular}{cc}
\hline Percentage & Category \\
\hline $0 \%-30 \%$ & Low \\
$>30 \%-60 \%$ & Moderate \\
$>60 \%-100 \%$ & High \\
\hline
\end{tabular}

This study uses two types of data, namely qualitative and quantitative. Expert validation, practitioner validation, and student responses were analyzed qualitatively. Student characters are also analyzed qualitatively based on the results of observations by researchers on student responses, limited to the potential of e-book to strengthen character. The effectiveness of the e-book in improving student understanding was analyzed quantitatively.

\section{RESULTS AND DISCUSSION}

\subsection{Analysis}

The analysis stage consists of a needs analysis and a final analysis. The analysis was carried out by interviewing the physics subject teacher and giving a questionnaire to 30 students of class XI who represented the entire class XI. The needs analysis informed that physics learning used a national curriculum related to character, the use of media was not optimal in learning, and the difficulty of understanding physics concepts, one of which was momentum and impulse..

The final analysis informed that students are interested in using multimedia learning. Teachers also expected teaching materials to be packaged in an attractive, interactive, contextual, and easily accessible way through student gadgets. The character also needs to be integrated into teaching materials in order to provide character reinforcement to students. Characters such as honest, disciplined, independent, curious, and communicative need to be reinforced. This is evidenced by the presence of students who cheat, are not on time in collecting assignments, have low curiosity, and lack communication between students due to the use of gadgets..

\subsection{Design}

The design stage produced a prototype of the Physics interactive e-book that is ready for use by users but still requires improvement in various aspects. This stage included the process of determining the required resources, material coverage, and creating a story board. The e-book developed is interactive, contains text, images, videos that can be accessed offline, exercises that can be accessed online and can provide quick feedback. Ebooks can be accessed using the PDF Foxit Reader. This program was chosen because it is easy to operate, easy to follow and run images, videos, audio, website links, and text.

The e-book developed consists of an introduction, content, and closing. The introductory section consists of the front cover page, introduction, table of contents, 
instructions for use, concept map, and a brief description of the contents of the E-book. The content section consists of lessons divided into 5 chapters, containing material, pictures, videos, and learning evaluations. The closing section contains bibliography and author profile information. The integration of characters is arranged by including character values in the content of the material, discussion and experiment sheets, evaluation, and character strengthening motivational sentences. Table 2 is an explanation of the contents of the e-book storyboard.

Table 2. Storyboard

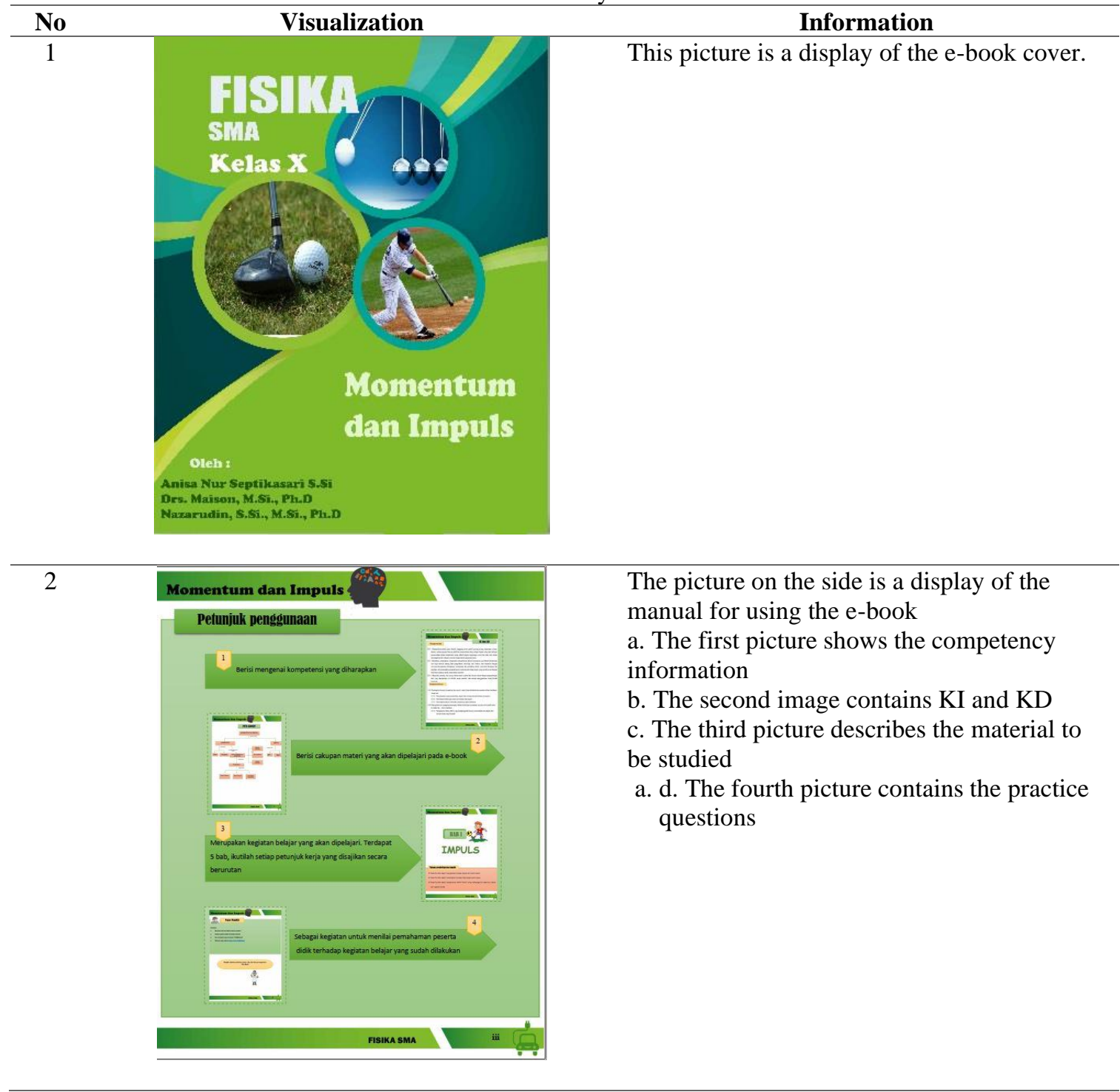




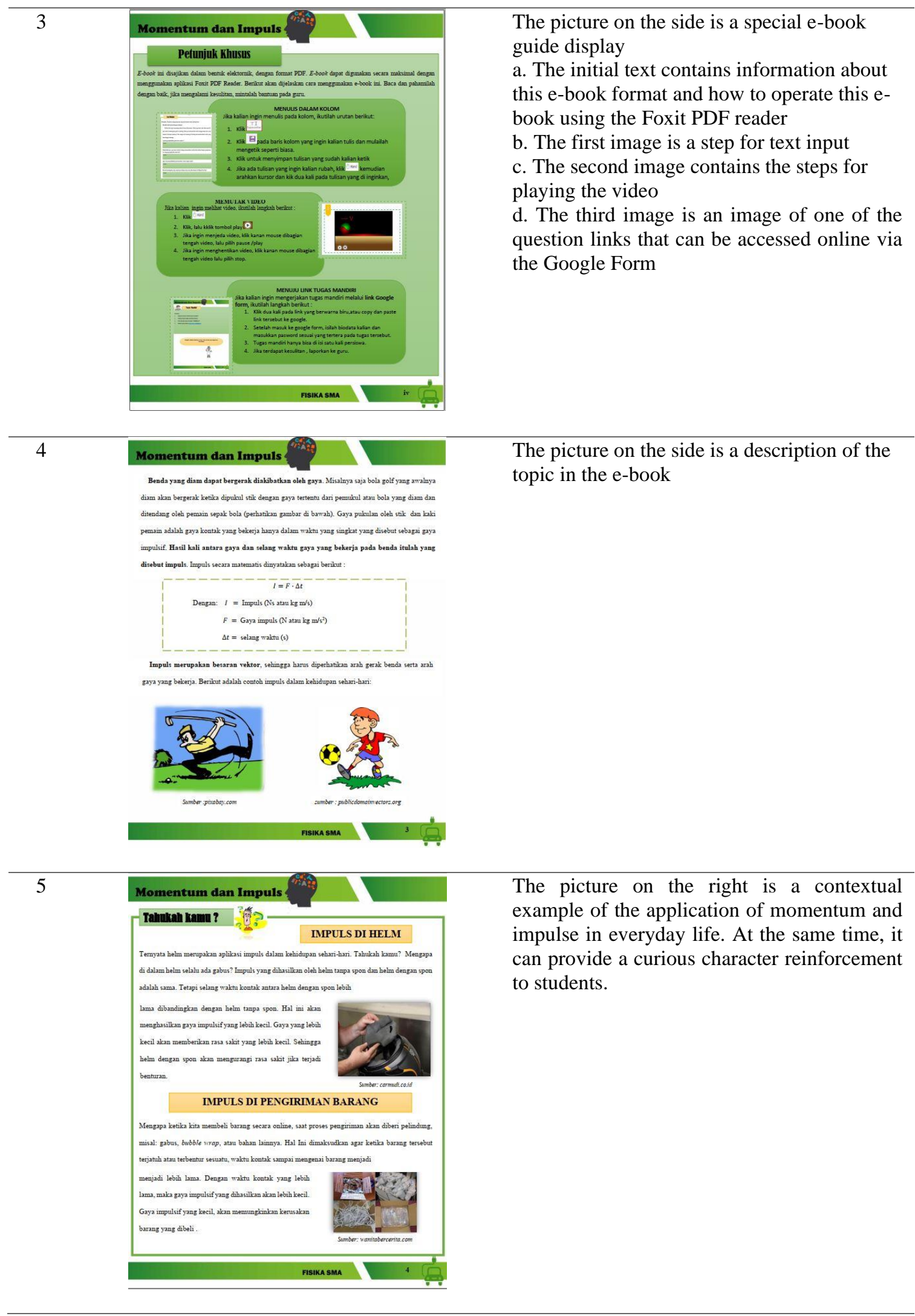




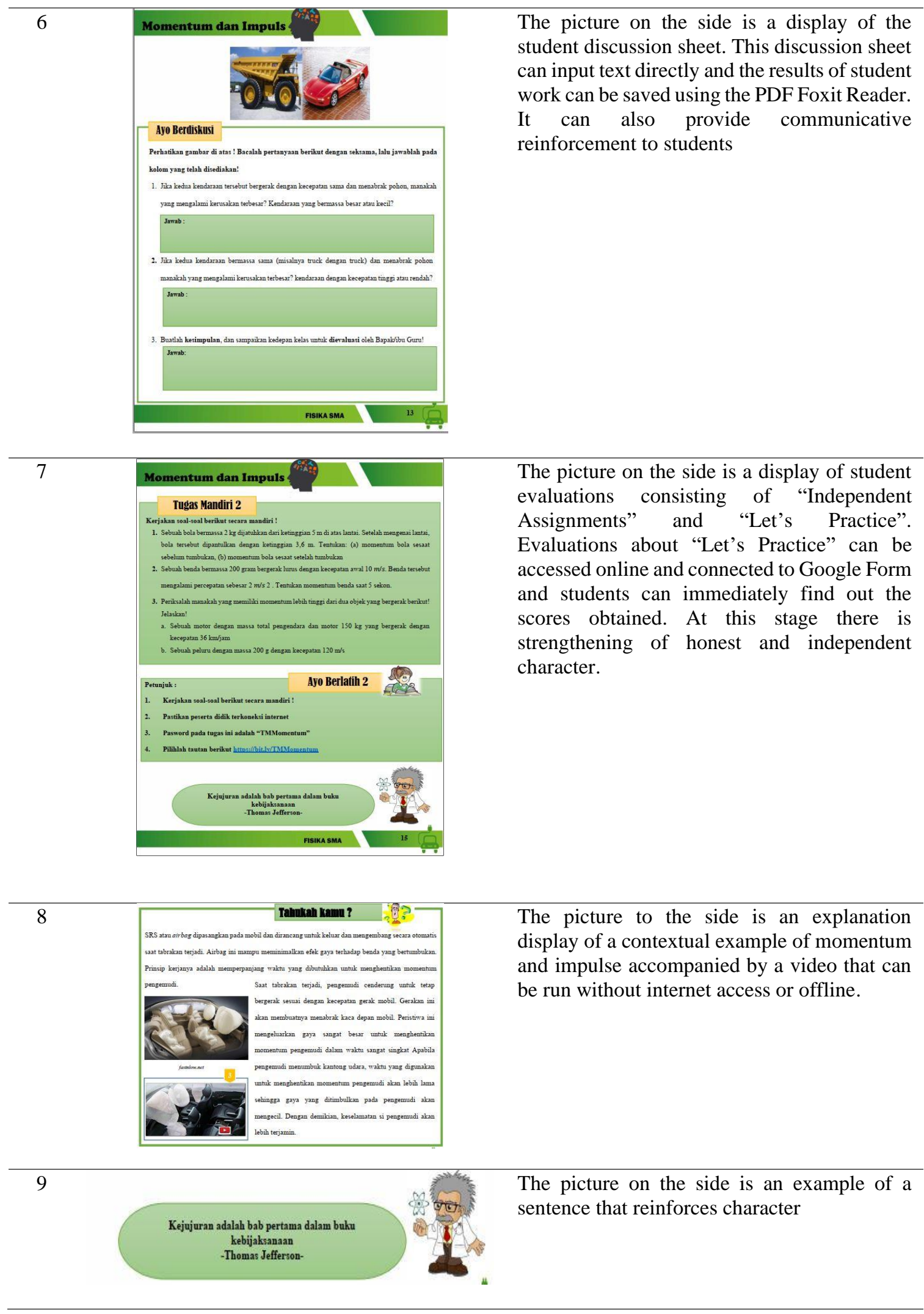

\subsection{Development and Implementation}

At the development stage of the e-book prototype, conceptual and practical improvements were made through the validation of learning design experts, material experts, media experts, and practitioners. Expert validation was carried out by lecturers at 
Jambi University, while practitioner validation was carried out by teacher as learning implementer.

The learning design validation process was carried out twice by providing responses to the e-book. The product is in accordance with the aspects of learning design, including analysis of needs, characteristics and learning environment, learning objectives, assessment instruments, and evaluation. Suggestions and comments from the validator on the first validation are related to learning scenarios, and attitude assessment instruments that must be in accordance with the objectives of the e-book. In the learning scenario, the validator suggested completing the lesson plan according to the e-book, so that the expected learning process and learning time are clear. The validator also suggested making attitude assessment indicators to be achieved in the e-book. The attitude assessment made according to the aims of the e-book is honest, disciplined, independent, curious, and communicative.

Validation of material experts was carried out twice. The validator provides detailed suggestions for improvements to the e-book content, such as providing information on the class of students who will use this e-book in the cover section, deepening the material regarding the direction of impulses and momentum, increasing examples and exercises that lead to students' ability to understand the concept of momentum and impulse. In addition, the validator also suggested increasing the variety of questions from C1-C6 in order to improve the development of students' cognitive abilities at a higher level. In the concept application section, the validator provides suggestions for adding the benefits of impulse and momentum to vehicle safety such as airbags in car.

Validation of product design experts was carried out twice. The product design expert validator responded well to this interactive e-book. The colors in the e-book are quite interesting, the e-book contains images, text, videos that are proportional and in accordance with the material content. Pictures and videos have been accompanied by a narrative that fits the topic. In addition there is the highlighting of important information in the presentation of lessons. The e-book is also accompanied by a guide so that students get information to use the e-book optimally. Interactive principles are also presented in the e-book, such as providing feedback quickly in integrating audio, video, and evaluation through google form. The suggestions that have been given by the validator do not change the content and appearance of the e-book as a whole. The validator provides input to include the name of the developer/author in the e-book.

Practitioner validation was carried out once with a positive response. Validator said that e-books can be used well in learning activities. According to the validator, this e-book is easy to use, interesting, complete with evaluation, and highly supports the online learning process. E-book can also facilitate to instill student character if used in learning activities. In addition, the validator also provides input on the Basic Competencies section of the e-book, because there are errors in the use of operational verbs in basic competencies that contain psychomotor abilities. Based on validation by the practitioner, after the e-book has been corrected, the e-book is feasible to be tested

The effectiveness of the e-book was measured based on the increase in students' understanding of concepts and decreased misconceptions of students through a four-tiered diagnostic test. The diagnostic results of pre-test and post-test misconceptions are shown in Table 3 below. 
Table 3. The Average Score on the Correct Answers in the Pre-test and Post-test

\begin{tabular}{cccccccccccc}
\hline Question Number & \multicolumn{3}{c}{$\mathbf{1}$} & \multicolumn{2}{c}{$\mathbf{2}$} & \multicolumn{3}{c}{$\mathbf{3}$} & \multicolumn{4}{c}{$\mathbf{4}$} & \multicolumn{2}{c}{ Mean } \\
\cline { 2 - 10 } & Pre & Post & Pre & Post & Pre & Post & Pre & Post & Pre & Post \\
\hline Tier 1 only & $14 \%$ & $88 \%$ & $45 \%$ & $61 \%$ & $8 \%$ & $78 \%$ & $53 \%$ & $61 \%$ & $30 \%$ & $76 \%$ \\
Tier 1 and 3 only & $14 \%$ & $78 \%$ & $16 \%$ & $35 \%$ & $0 \%$ & $76 \%$ & $33 \%$ & $47 \%$ & $16 \%$ & $63 \%$ \\
All Tier & $8 \%$ & $71 \%$ & $10 \%$ & $35 \%$ & $0 \%$ & $73 \%$ & $22 \%$ & $41 \%$ & $10 \%$ & $60 \%$ \\
\hline
\end{tabular}

The pre-test results in Table 3 show that most students answered correctly in tier one, namely $30 \%, 16 \%$ for tier one and three, and 10\% for all tiers. Based on the results of the percentage of correct scores for all the tiers, it is known that the number of students who understand the concepts in the impulse and momentum material is classified into the low category because the percentage of understanding the concept obtained is $<30 \%$ [21][31].

Based on Table 3, it can be seen that the results of the post-test, on average, students answered correctly for tier one, which was $76 \%$, tier one and three were $63 \%$, and the percentage for all tier was $60 \%$. Based on the results of the percentage of correct scores for all tiers or those concluded as students who understand the concept, they are classified into the moderate category, because the percentage of understanding the concept obtained reaches $60 \%$ [21][31]. So that there is an increase in understanding of the concept before and after using the e-book. The results of this study are in line with the findings of previous studies which reveal that interactive e-books can improve student learning experiences [1][15][16].

Based on Table 3, it can be seen that the highest correct score is the correct score in tier one, then the correct score for tier one and three, finally the correct score for all tier. The average correct score in tier one at pre-test is $30 \%$ and post-test is $76 \%$. The percentage of the tier one score is always higher because the instrument is in the form of ordinary multiple choice questions, so the reasons and beliefs of students choosing answers are not seen if the students answer correctly [21]. If the students answered correctly on tier one it is not said that they fully understand the concept, because there is a possibility that the student is only guessing.

The correct score in tier one and three at the pre-test was $16 \%$ and when the post-test increased to $63 \%$, this score was lower than the score of the first tier. This is because the correct score is based on the student's choice and reason, if the answer and reason are correct then the score is 1 . Then if the answer is correct and the reason is wrong, or vice versa, the score obtained is 0 .

The result for correct scores on all tier in the pre-test, the percentage is $10 \%$ and on the post-test $60 \%$, these scores are lower than the scores for tier one and three. This is because the correct score for all tier is seen based on the answers, reasons, and the level of confidence of students in choosing answers and reasons. If the student chose the correct answer and reason, as well as the level of confidence in choosing the answer and the reason is sure, then the score is 1 . However, if from the four tiers the student is wrong or unsure then the score is 0 .

Based on Table 4, it can be seen that the largest percentage of misconceptions occurs in the concept of conservation of energy in collisions, the results of this study are the same as the findings in Anggraeni's research [13]. There is a change in the percentage of misconceptions in the pre-test and post-test. This is in line with previous research which stated that interactive e-book and problem-based learning model can remediate student misconceptions [15][14]. However, in the matter of the kinetic energy of objects after the collision, there was no change in the percentage of misconceptions, which was still 5\%. So that other learning methods or strategies are needed to remediate students' misconceptions on this concept [18]. 
Table 4. Percentage of Misconceptions in Pre-test and Post-test

\begin{tabular}{|c|c|c|c|}
\hline \multirow{2}{*}{ Concept } & \multirow{2}{*}{ Misconception } & \multicolumn{2}{|c|}{ Percentage } \\
\hline & & Pre-test & Post-Test \\
\hline \multirow{4}{*}{$\begin{array}{l}\text { The conservation law of } \\
\text { momentum }\end{array}$} & The path length determines the object's final velocity & $0 \%$ & $0 \%$ \\
\hline & Time determines the object's final velocity & $0 \%$ & $0 \%$ \\
\hline & $\begin{array}{l}\text { The path length and time determine the object's final } \\
\text { velocity }\end{array}$ & $0 \%$ & $0 \%$ \\
\hline & Objects keep moving even though the energy is gone & $1 \%$ & $0 \%$ \\
\hline Perfect elastic collision & $\begin{array}{l}\text { The direction of motion of the object does not change } \\
\text { in a perfect elstic collision }\end{array}$ & $4 \%$ & $0 \%$ \\
\hline Momentum & $\begin{array}{l}\text { The magnitude of the momentum of an object is only } \\
\text { determined by the mass of the object }\end{array}$ & $0 \%$ & $0 \%$ \\
\hline \multirow[t]{2}{*}{$\begin{array}{l}\text { Energy conservation on } \\
\text { collision }\end{array}$} & $\begin{array}{l}\text { The kinetic energy of the object after the collision } \\
\text { becomes zero if the mass of the colliding object is } \\
\text { equal }\end{array}$ & $6 \%$ & $4 \%$ \\
\hline & $\begin{array}{l}\text { The kinetic energy of the object after the collision } \\
\text { becomes zero if the velocity of the colliding object is } \\
\text { equal }\end{array}$ & $5 \%$ & $5 \%$ \\
\hline
\end{tabular}

\subsection{Evaluation}

The evaluation stage is carried out to determine the response to the resulting product [25]. The response to individual trial results reveals that the e-book is easy to use on smartphones and has clear instructions for use. Students are attracted by the appearance of the e-book which is compatible with colors, there are videos, clear sample questions, and there are online exercises that are connected to the google form. Students also provide suggestions for developers to make e-book barcodes to make it easier to access interactive e-books.

Based on small-group trials, students expressed interest and stated that they understood the explanations contained in the e-book. Based on the results of observations when the respondent used the e-book, it was seen that the students had curiosity in understanding the topic of momentum and impulse, even though the students had studied this topic in the previous semester. Students appear independent when answering online exercises available in the e-book. In addition, students are very disciplined in following directions and instructions given during product trials. Communication also occurs between students when discussing the problem of physics concepts contained in the ebook.

Based on student responses to individual and small group trials, this e-book has the advantage of containing images, videos, online exercises, text input facilities, and can be accessed via smartphones and has the potential to provide character strengthening to students. This can help students learn to improve students' understanding of the topic of momentum and impulse without being limited by time and space.

\section{CONCLUSION}

Based on the research and development results of the impact of an interactive e-book on high school physics learning, it can be concluded that the development of interactive ebooks has been recognized as feasible and easy to use by students and has the potential to provide character strengthening. This is based on the results of expert validation, practitioner validation, student responses. This research does not reach the character improvement test, but only observes the potential for character strengthening when students use the e-book. There was an increase in concept understanding from $10 \%$ in the low category to $60 \%$ with the moderate category. 


\section{REFERENCES}

[1] Y. M. Huang, T. H. Liang, Y. N. Su, and N. S. Chen, "Empowering personalized learning with an interactive e-book learning system for elementary school students," Educ. Technol. Res. Dev., vol. 60, no. 4, pp. 703-722, 2012.

[2] H. Jeong, "A comparison of the influence of electronic books and paper books on reading comprehension, eye fatigue, and perception," Electron. Libr., vol. 30, no. 3, pp. 390-408, 2012.

[3] R. Adawiyah, A. Harjono, G. Gunawan, and H. Hermansyah, "Interactive e-book of physics to increase students' creative thinking skills on rotational dynamics concept," J. Phys. Conf. Ser., vol. 1153, no. 1, 2019.

[4] P. A. Chusna, "Pengaruh Media Gadget Pada Perkembangan Karakter Anak," Din. Penelit. Media Komun. Sos. Keagamaan, vol. 17, no. 2, pp. 315-330, 2017.

[5] J. Syahbrudin, "Multimedia Interaktif Berbasis Karakter sebagai upaya Peningkatan Nilai-Nilai Karakter dan Kemampuan Berpikir Tingkat Tinggi," Comput. Eng. Sci. Syst. J., vol. 3, no. 1, p. 7, 2018.

[6] P. Suparno, Sumbangan Pendidikan Fisika terhadap Pembangunan Karakter Bangsa. Yogyakarta: USD, 2012.

[7] P. Mulhall and R. Gunstone, "Views About Learning Physics Held by Physics Teachers with Differing Approaches to Teaching Physics," J. Sci. Teacher Educ., vol. 23, no. 5, pp. 429-449, 2012.

[8] Y. Sudarmini, K. -, and A. S. Hadiwijaya, "Pembelajaran Fisika Berbasis Inkuiri Terbimbing Dengan Menggunakan Lks Untuk Meningkatkan Keterampilan Berpikir Kritis Ditinjau Dari Sikap Ilmiah Siswa Madrasah Aliyah Qamarul Huda Bagu Lombok Tengah," J. Penelit. Pendidik. IPA, vol. 1, no. 1, pp. 35-48, Jan. 2015.

[9] L. D. Herliandry, A. Harjono, and J. 'Ardhuha, "Kemampuan Berpikir Kritis Fisika Peserta Didik Kelas X dengan Model Brain Based Learning," J. Penelit. Pendidik. IPA, vol. 5, no. 1, 2018.

[10] S. Siswadi, S. Susilawati, and H. Hikmawati, "Pengaruh Pendekatan Vak (Visualization, Auditory, Kinestetic) Terhadap Hasil Belajar Fisika Siswa Smpn 10 Mataram,” J. Penelit. Pendidik. IPA, vol. 4, no. 1, 2018.

[11] F. X. Berek, S. Sutopo, and M. Munzil, "Concept enhancement of junior high school students in hydrostatic pressure and archimedes law by predict-observe-explain strategy," J. Pendidik. IPA Indones., vol. 5, no. 2, pp. 230-238, 2016.

[12] A. Hidayat, S. H. B. Prastowo, and B. Supriadi, "Identifikasi miskonsepsi momentum, impuls dan tumbukan melalui tes diagnostik empat tahap pada siswa SMA kelas XII," Semin. Nas. Pendidik. Fis., vol. 2, no. 1, pp. 227-234, 2017.

[13] D. Anggraraeni and S. S, "Diagnosis Miskonsepsi Siswa Pada Materi Momentum, Impuls, Dan Tumbukan Menggunakan Three-Tier Diagnostic Test," Inov. Pendidik. Fis., vol. 6, no. 3, pp. 271-274, 2017.

[14] O. Akinoğlu and R. Ö. Tandoğan, "The effects of problem-based active learning in science education on students' academic achievement, attitude and concept learning," Eurasia J. Math. Sci. Technol. Educ., vol. 3, no. 1, pp. 71-81, 2007.

[15] M. Hidayatulloh, I. Wiryokusumo, and D. A. Walujo, "Remidiasi Miskonsepsi Siswa Pada Materi Listrik Dinamis Menggunakan Ebook Interaktif,” J. Pendidik. Fis. dan Teknol., vol. 5, no. 1, p. 30, Mar. 2019, doi: 10.29303/jpft.v5i1.986.

[16] K. N. Imani and I. G. M. Sanjaya, "Pengembangan E-Book Interaktif," UNESA J. Chem. Educ., vol. 1, no. 2, pp. 7-10, 2012.

[17] I. N. Sugiana, A. Harjono, and H. Sahidu, "Pengaruh Model Pembelajaran Generatif 
Berbantuan Media Laboratorium Virtual Terhadap Penguasaan Konsep Fisika Siswa pada Materi Momentum dan Impuls,” vol. II, no. 2, pp. 61-65, 2016.

[18] N. D. Handayani, S. Astutik, and A. D. Lesmono, "Diagnostic Test Pada Materi Hukum Termodinamika," J. Pembelajaran Fis., vol. 7, no. 2, pp. 189-195, 2018.

[19] D. Kaltakci-Gurel, A. Eryilmaz, and L. C. McDermott, "Development and application of a four-tier test to assess pre-service physics teachers' misconceptions about geometrical optics," Res. Sci. Technol. Educ., vol. 35, no. 2, pp. 238-260, 2017, [Online]. Available: http://dx.doi.org/10.1080/02635143.2017.1310094.

[20] I. Kaniawati, N. J. Fratiwi, A. Danawan, I. Suyana, A. Samsudin, and E. Suhendi, "Analyzing students' misconceptions about Newton's Laws through Four-Tier Newtonian Test (FTNT)," J. Turkish Sci. Educ., vol. 16, no. 1, pp. 110-122, 2019.

[21] M. Maison, N. Lestari, and A. Widaningtyas, "Identifikasi Miskonsepsi Siswa Pada Materi Usaha Dan Energi," J. Penelit. Pendidik. IPA, vol. 6, no. 1, p. 32, 2019.

[22] Rohmani, W. Sunarno, and Sukarmin, "Pengembangan Media Pembelajaran Fisika Berbasis Multimedia Interaktif Terintegrasi Dengan Lks Pokok Bahasan Hukum Newton Tentang Gerak Kelas X Sma/Ma,” Inkuiri, vol. 4, no. 1, pp. 152-162, 2016.

[23] D. Nugraha and Wasis, "Pengembangan Media E-Book Interaktif Bilingual Pada Materi Pokok Kalor Untuk Sma Kelas X,” vol. 03, no. 01, pp. 1-7, 2014.

[24] A. Hidayat, A. Suyatna, and W. Suana, "Pengembangan Buku Elektronik Interaktif Pada Materi Fisika Kuantum Kelas Xii Sma," J. Pendidik. Fis., vol. 05, no. 02, pp. 87-101, 2017.

[25] W. Lee and D. Owens, Multimedia Based Instructional Design. San Fransisco: Pfeiffer, 2004.

[26] Sugiyono, Metode Penelitian Pendidikan; Pendekatan Kuantitatif, Kualitatif, dan $R \& D$, Second Edi. Bandung: Alfabeta, 2014.

[27] H. Uno and S. Koni, Assesmen pembelajaran, 1st ed. Jakarta: Bumi Aksara, 2014.

[28] M. Rusdi, Penelitian Desain dan Pengembangan Kependidikan. Jakarta: Rajawali Press, 2018.

[29] L. Hanifah and F. Ermawati, "the Validity and Reliability of Four-Tier Format Misconception Diagnostic Test Instrument for Momentum and Impulse Concepts," Inov. Pendidik. Fis., vol. 8, no. 2, pp. 575-578, 2019.

[30] D. S. Jubaedah, I. Kaniawati, I. Suyana, A. Samsudin, and E. Suhendi, "Pengembangan Tes Diagnostik Berformat Four-Tier Untuk Mengidentifikasi Miskonsepsi Siswa Pada Topik Usaha Dan Energi," in Prosiding Seminar Nasional Fisika (E-Journal) SNF 2017 UNJ, 2017, vol. VI, pp. SNF2017-RND-35-SNF2017RND-40.

[31] L. Istighfarin, "Profil Miskonsepsi Siswa Pada Materi Struktur dan Fungsi Jaringan Tumbuhan,” vol. 6, no. 1, pp. 21-30, 2017. 